\title{
Penile Length: A Study in Iranian Military Soldiers
}

\author{
Hamed Mohseni Rad ${ }^{1}$ iD
}

1. Department of Surgery, School of Medicine and Allied Medical Sciences, Imam Reza Hospital, Ardabil University of Medical Sciences, Ardabil, Iran

\begin{tabular}{|c|c|}
\hline Article Information & Abstract \\
\hline Article History & Background \& Objective: Penile size is of great importance between \\
\hline $2019 / 10 / 06$ & some men and they are looking for a longer penis. The number of urologists \\
\hline Accepted: $\quad 2020 / 01 / 14$ & visiting for complaining about short penis is increasing. Therefore, provid- \\
\hline Available Online: $2020 / 05 / 24$ & ing a definition of normal penis size can help Iranian physicians and patients. \\
\hline JUR 2019; 3(2):33-40 & $\begin{array}{l}\text { Methods: This study was performed as a cross-sectional descriptive } \\
\text { study in 1396-97 at Imam Sajjad Hospital in Tehran. In this study, simple }\end{array}$ \\
\hline DOI: 10.30699/jru.3.2.33 & random sampling of 500 soldiers referred to the urology department of Imam \\
\hline Use your device to scan & $\begin{array}{l}\text { Sajjad Hospital. Data were collected by urologists. After collecting the data, } \\
\text { it entered the spss } 21 \text { for analysis. }\end{array}$ \\
\hline and read th & $\begin{array}{l}\text { Results: Our study on Iranian military soldiers consisting of all prov- } \\
\text { inces showed that mean penile flaccid length is } 7.87 \mathrm{~cm} \text {, stretched length is } \\
12.22 \mathrm{~cm} \text { and mid shaft circumference is } 8.49 \mathrm{~cm} \text {. Differences among prov- } \\
\text { inces were not significant. There was no association between age and height } \\
\text { with penile parameters. }\end{array}$ \\
\hline Corresponding Author & $\begin{array}{l}\text { Conclusions: Our study shows that in Iranian soldiers from every prov- } \\
\text { ince, there was no significant penile parameter differences nor significant } \\
\text { correlation with their height and age. These data may help urologists to reas- } \\
\text { sure and inform men who are concerned about their penile size. }\end{array}$ \\
\hline $\begin{array}{l}\text { Hamed Mohseni Rad } \\
\text { Department of Surgery, } \\
\text { School of Medicine and } \\
\text { Allied Medical Sciences, } \\
\text { Imam Reza Hospital, Ard- } \\
\text { abil University of Medical } \\
\text { Sciences, Ardabil, Iran }\end{array}$ & Keywords: Penile length, Penis circumference, Age, Height \\
\hline $\begin{array}{l}\text { Tel: (+98) } 9126484037 \\
\text { Email: } \\
\text { sirhamed2@gmail.com }\end{array}$ & \\
\hline
\end{tabular}

How to cite this article:

Mohseni Rad H. Penile Length: A Study in Iranian Military Soldiers. J Res Urol. 2019; 3 (2) : 


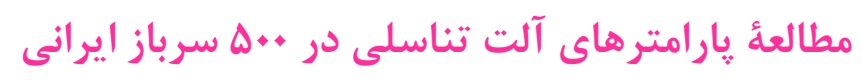

حامد محسنى راد!: (1)

1. كَروه جراحى، دانشكده يزشكى و پيرايزشكى. بيمارستان امام رضا (ع). دانشعاه علوم يزشكى اردبيل، اردبيل، ايران

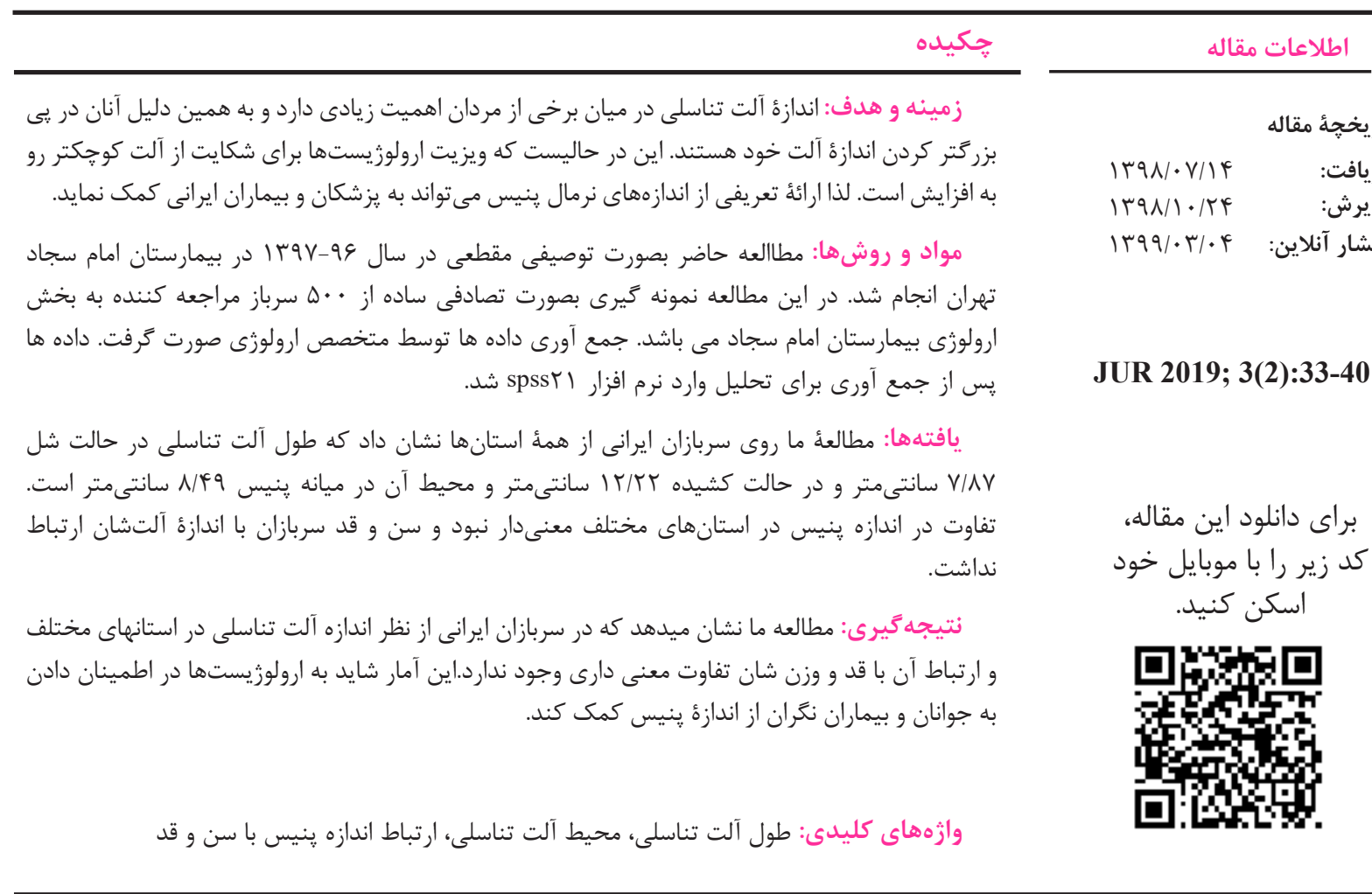

نويسنده مسئول: حامد محسنى راد، كروه جراحى، دانشكده يزشكى و يِرايزشكى. بيمارستان امام رضا (ع). دانشكاه علوم يزشكى اردبيل، اردبيل، ايران

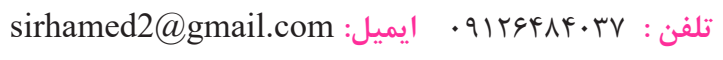




\section{Introduction}

Penile size is of great importance for male patients, but few high-quality data exists on this subject in Iran, particularly in different ethnic groups $[1,2]$. The exact measurement of penile parameters are most important in diagnosing penile problems such as micropenis [3].

Desire for a longer penile size was a concern for $68.3 \%$ of 200 men in one study, so it is a common concern in the male population $[4,5]$. Concerns about penile size affect men's sexual satisfaction and functioning [6]. Penile size does not affect sexual functions like orgasm, sexual drive, or pain experience. However, men who are less satisfied with their penis, report more sexual health problems [7]. However, penile length is normal in most men seeking penile lengthening procedures [4]. Accurate regional penile assessment and informing the men and the couples of that region about common penile dimensions may increase their sexual satisfaction. In this study 500 soldiers enrolled from all provinces of Iran. This study aimed to assess the penile parameters in healthy Iranian soldiers, to estimate the penile sizes in physically normal males younger than 30 years old, as well as to correlate the resulting values with age, height and ethnicity, to provide data that could be clinically applicable by the practicing urologists.

\section{Materials and Methods}

This study was performed as a cross-sectional descriptive study in 1396-97 at Imam Sajjad Hospital in Tehran. In this study, simple random sampling of 500 soldiers referred to the urology department of Imam Sajjad Hospital. In this study 500 soldiers (mean age 22.4; range 18-32) presented to our urologic outpatient clinic in a military Hospital. Exclusion criteria included, complaint of small or short penis, Peyronie's disease, congenital curvature, clinical hypogonadism and previous penile surgery or trauma. Data were collected by urologists.

Ruler measurement of flaccid and stretched penis and tape measurement of flaccid penile circumference and soldiers' height were made in centimeters with a decimal point. To measure the total penile length. We placed the butt of a rigid ruler on the pubic skin over the dorsum of the penis in flaccid and stretched conditions. The distance between the pubic skin and the external urethral meatus was recorded. The penile circumference or girth was measured at the midshaft. The height was measured as routine. The resultant values were matched with the age, height and ethnicity.

The examination room was quiet, comforting, and with the temperature between $20^{\circ} \mathrm{C}$ and $25^{\circ} \mathrm{C}$ to alleviate any anxiety and to permit relaxation of the external genitalia. After collecting the data, it entered the spss 21 for analysis.

\section{Results}

Our study was conducted on a group of Iranian military soldiers consisting of almost all provinces included 500 men with mean age of $22.57 \mathrm{y} /$ old ranging from $18 \mathrm{y} / \mathrm{o}$ to $35 \mathrm{y} / \mathrm{o}$. Their mean height was $176.93 \mathrm{~cm}$ ranging from $152 \mathrm{~cm}$ to $195 \mathrm{~cm}$.

The mean penile flaccid length was $7.87 \pm 1.45$ $\mathrm{cm}$, stretched length was $12.22 \pm 2.43 \mathrm{~cm}$ and mid shaft circumference was $8.49 \pm .76 \mathrm{~cm}$. Differences among provinces were not statistically significant (Table 1).

In addition, we did not find any correlation among penile flaccid and stretched length and circumference.

There were no association between soldiers' height and penile parameters. Also, we did not find any significant correlation between age and penile parameters in this group of soldiers. 


$$
\text { حامد محسنى راد | مطالعهُ پارامترهاى آلت تناسلى در •ـ سرباز ايرانى }
$$

Table 1. Penile length in Flaccid and Stretched situations and penile flaccid mid shaft circumference in different cities of Iran

\begin{tabular}{|c|c|c|c|c|}
\hline \multicolumn{2}{|l|}{ City } & \multirow{2}{*}{$\begin{array}{l}\text { Flaccid } \\
7.477\end{array}$} & \multirow{2}{*}{$\begin{array}{c}\text { Stretched } \\
11.737 \\
\end{array}$} & \multirow{2}{*}{$\begin{array}{c}\text { Circumference } \\
8.384 \\
\end{array}$} \\
\hline \multirow{3}{*}{ Ardabil } & Mean & & & \\
\hline & $\mathrm{N}$ & 43 & 43 & 43 \\
\hline & Variance & 1.379 & 2.329 & 833. \\
\hline \multirow{3}{*}{ Markazi } & Mean & 8.300 & 12.253 & 8.513 \\
\hline & $\mathrm{N}$ & 15 & 15 & 15 \\
\hline & Variance & 1.130 & 2.147 & 403. \\
\hline \multirow{3}{*}{ Kermanshah } & Mean & 8.529 & 13.386 & 8.843 \\
\hline & $\mathrm{N}$ & 7 & 7 & 7 \\
\hline & Variance & 2.322 & 4.691 & 1.346 \\
\hline \multirow{3}{*}{ Lorestan } & Mean & 7.365 & 12.165 & 8.395 \\
\hline & $\mathrm{N}$ & 20 & 20 & 20 \\
\hline & Variance & 2.353 & 3.519 & 854. \\
\hline \multirow{3}{*}{ Sistan baluchestan } & Mean & 8.400 & 11.950 & 8.450 \\
\hline & $\mathrm{N}$ & 4 & 4 & 4 \\
\hline & Variance & 4.047 & 3.777 & 150. \\
\hline \multirow{3}{*}{ Hamadan } & Mean & 8.070 & 12.391 & 8.500 \\
\hline & $\mathrm{N}$ & 23 & 23 & 22 \\
\hline & Variance & 2.293 & 3.143 & 569. \\
\hline \multirow{3}{*}{ Isfahan } & Mean & 7.814 & 12.300 & 8.657 \\
\hline & $\mathrm{N}$ & 7 & 7 & 7 \\
\hline & Variance & 251. & 563. & 790. \\
\hline \multirow{3}{*}{ Ilam } & Mean & 8.260 & 13.140 & 8.800 \\
\hline & $\mathrm{N}$ & 5 & 5 & 5 \\
\hline & Variance & 1.413 & 898. & 1.690 \\
\hline \multirow{3}{*}{ Qazvin } & Mean & 8.019 & 12.530 & 8.681 \\
\hline & $\mathrm{N}$ & 27 & 27 & 27 \\
\hline & Variance & 1.332 & 2.849 & 615. \\
\hline \multirow{3}{*}{ Kohkiluyeboyerahmad } & Mean & 7.967 & 11.467 & 8.067 \\
\hline & $\mathrm{N}$ & 3 & 3 & 3 \\
\hline & Variance & 0.003 & 173. & 0.143 \\
\hline \multirow{3}{*}{ Fars } & Mean & 7.717 & 12.083 & 8.367 \\
\hline & $\mathrm{N}$ & 6 & 6 & 6 \\
\hline & Variance & 0.602 & 1.642 & 1.259 \\
\hline \multirow{3}{*}{ Azarbaijan Sharghi } & Mean & 8.079 & 12.693 & 8.857 \\
\hline & $\mathrm{N}$ & 28 & 28 & 28 \\
\hline & Variance & 1.368 & 1.621 & 988. \\
\hline \multirow{3}{*}{ Hormozgan } & Mean & 8.525 & 12.875 & 8.050 \\
\hline & $\mathrm{N}$ & 4 & 4 & 4 \\
\hline & Variance & 0.302 & 1.063 & 0.437 \\
\hline
\end{tabular}




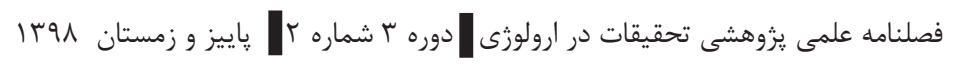

\begin{tabular}{|c|c|c|c|c|}
\hline \multicolumn{2}{|l|}{ City } & \multirow{2}{*}{$\begin{array}{c}\text { Flaccid } \\
7.500\end{array}$} & \multirow{2}{*}{$\begin{array}{c}\text { Stretched } \\
11.950\end{array}$} & \multirow{2}{*}{$\begin{array}{c}\text { Circumference } \\
8.600\end{array}$} \\
\hline \multirow{3}{*}{ Khorasan } & Mean & & & \\
\hline & $\mathrm{N}$ & 8 & 8 & 8 \\
\hline & Variance & 1.429 & 6.166 & 0.880 \\
\hline \multirow{3}{*}{ Alborz } & Mean & 8.041 & 12.255 & 8.645 \\
\hline & $\mathrm{N}$ & 22 & 22 & 22 \\
\hline & Variance & 1.213 & 2.560 & 0.568 \\
\hline \multirow{3}{*}{ Qom } & Mean & 7.386 & 11.386 & 8.257 \\
\hline & $\mathrm{N}$ & 7 & 7 & 7 \\
\hline & Variance & 1.051 & 1.241 & 0.226 \\
\hline \multirow{3}{*}{ Khuzestan } & Mean & 8.300 & 12.383 & 8.267 \\
\hline & $\mathrm{N}$ & 6 & 6 & 6 \\
\hline & Variance & 2.140 & 1.982 & 0.591 \\
\hline \multirow{3}{*}{ Kerman } & Mean & 9.025 & 13.225 & 8.500 \\
\hline & $\mathrm{N}$ & 4 & 4 & 4 \\
\hline & Variance & 1.642 & 9.149 & 0.620 \\
\hline \multirow{3}{*}{ Semnan } & Mean & 7.625 & 12.225 & 8.700 \\
\hline & $\mathrm{N}$ & 4 & 4 & 4 \\
\hline & Variance & 1.576 & 4.203 & 0.927 \\
\hline \multirow{3}{*}{ Chaharmahalbakhtiari } & Mean & 7.775 & 13.100 & 8.338 \\
\hline & $\mathrm{N}$ & 8 & 8 & 8 \\
\hline & Variance & 0.962 & 3.383 & 0.251 \\
\hline \multirow{3}{*}{ Yazd } & Mean & 7.900 & 12.700 & 8.850 \\
\hline & $\mathrm{N}$ & 4 & 4 & 4 \\
\hline & Variance & 1.773 & 1.827 & 0.870 \\
\hline \multirow{3}{*}{ Bushehr } & Mean & 8.300 & 12.167 & 8.133 \\
\hline & $\mathrm{N}$ & 3 & 3 & 3 \\
\hline & Variance & 0.010 & 143. & 0.143 \\
\hline \multirow{3}{*}{ Azarbaijan Gharbi } & Mean & 8.139 & 12.278 & 8.461 \\
\hline & $\mathrm{N}$ & 18 & 18 & 18 \\
\hline & Variance & 1.760 & 1.859 & 1.495 \\
\hline \multirow{3}{*}{ Kurdestan } & Mean & 8.100 & 12.400 & 8.360 \\
\hline & $\mathrm{N}$ & 10 & 10 & 10 \\
\hline & Variance & 0.544 & 1.656 & 1.178 \\
\hline \multirow{3}{*}{ Tehran } & Mean & 7.795 & 12.079 & 8.494 \\
\hline & $\mathrm{N}$ & 138 & 138 & 138 \\
\hline & Variance & 1.404 & 2.472 & 0.724 \\
\hline \multirow{3}{*}{ Gilan } & Mean & 7.673 & 12.127 & 8.273 \\
\hline & $\mathrm{N}$ & 26 & 26 & 26 \\
\hline & Variance & 1.406 & 1.801 & 0.612 \\
\hline
\end{tabular}

rv 
حامد محسنى راد | مطالعd پارامترهاى آلت تناسلى در •ه سرباز ايرانى

\begin{tabular}{|c|c|c|c|c|}
\hline City & & Flaccid & Stretched & Circumference \\
\hline \multirow{3}{*}{ Mazandaran } & Mean & 7.671 & 12.136 & 8.114 \\
\hline & $\mathrm{N}$ & 14 & 14 & 14 \\
\hline & Variance & 1.107 & 2.253 & 0.984 \\
\hline \multirow{3}{*}{ Golestan } & Mean & 8.287 & 12.760 & 8.540 \\
\hline & $\mathrm{N}$ & 15 & 15 & 15 \\
\hline & Variance & 1.647 & 1.964 & 0.978 \\
\hline \multirow{3}{*}{ Zanjan } & Mean & 7.591 & 11.273 & 8.818 \\
\hline & $\mathrm{N}$ & 11 & 11 & 11 \\
\hline & Variance & 1.891 & 970. & 918. \\
\hline \multirow{3}{*}{ Total } & Mean & 7.871 & 12.220 & 8.499 \\
\hline & $\mathrm{N}$ & 490 & 490 & 489 \\
\hline & Variance & 1.458 & 2.438 & 0.764 \\
\hline
\end{tabular}

\section{Discussion}

There are many young men consulting with urologist about their penile size that may even direct them to penile lengthening operation. However, urologists should be aware of the psychological background of such patients, as some patients may have hidden psychological problems. There are problems that cannot be relieved by surgery alone [8]. On the other hand, in our country, physicians do not have reliable data about penile parameters to refer especially in different ethnicity. Almost all of the reports are from other countries and races.

Our study has been performed prospectively on a group of military soldiers from every region of Iran then it can be a reliable Iranian standard of penile parameters in young men ranging from 18 to 32 years old. In this study, we only measured the penile dimensions in the flaccid and stretched state. In our Islamic country owing to ethical concerns and religious beliefs, we could not measure penile parameters in erect state. In one study, men have measured their penile length by themselves, however, this measurement may be inaccurate [9] However, it is evident that stretched penile length is dependent upon factors like the stretching force or number of stretching. To prevent these problems, one researcher measured all penile lengths with a maximal constant stretching force at one attempt. However, some studies showed that stretched penile measurement offers a good alternative to erect and flaccid penile length measurements [10-13].

Penile flaccid length in our study is similar with an Indian study but penile stretched length and circumference were significantly longer and thinner [14]. Comparing he results of the study by Khan $\mathrm{S}$. et al. in the UK to our findings, British men have longer penis than men in Iran. The mean values of flaccid and stretched penis in British men are $8.7 \mathrm{~cm}$ and $14.3 \mathrm{~cm}$ compared to $7.8 \mathrm{~cm}$ and $12.2 \mathrm{~cm}$ in Iranian men [15]. Our data showed that penile parameters had no significant association with height or age of the studied group. Although in a systematic review by Veale D. et al. there is a significant correlation between penile flaccid stretched or erect length with height [16]. The soldiers were asked about their penile size before the study and usually their estimations were more than the truth. But regarding to soldiers fearing of sexual behavior (penile dysmorphophobia) [15], penile calculating was less than the truth. The data confirmed the results of previous studies where young men tended to underestimate their penile size $[8,12]$. Therefore, we have to raise general information about usual penile size in young men of our country to lessen their agitation and then vain urologic office referral. Those who think that they have a small penis are anxious, apprehen- 
sive, and with a wide variety of fears. They tend to make minor problems to major sources of concern and dissatisfaction [8]. In addition, they are likely to show excessive concerns over their body functions, especially in the circulatory, digestive or urinary organs [8]. As penile size is dependent on androgens and testicular size, we excluded any unhealthy man regarding testis and breast examination and body hair pattern.

The definition of normal penile size has become an interest in performing correct assessments and therapeutic choices in patients who are concerned about penile parameters. A man's self-esteem can be affected by his penile parameters, mainly penile size [2]. If a man thinks his penis is inadequate, negative feelings would intervene his relation with his sexual partner [8]. Seeking for penile augmentation in different countries is increasing [2]. However, penile augmentation seems to be in its experimental period and its indications have not yet been clearly established and it is accompanied with many complications [8]. It has been suggested that just men with an erected length of less than $10 \mathrm{~cm}$ might be difficult for penetrance but stretched length of less than $7.5 \mathrm{~cm}$ should be candidates of penile lengthening [10]. However, patients may not be satisfied after these surgeries [17]. Two and half standard deviation below mean penile size is assumed as micropenis [18]. Although pediatric micropenis could be corrected with hormonal therapy, adult micropenis treatment is challenging [19]. Penile mechanical extenders, prepubic fat excision and suspensory ligament division are available options [20].

If penile length in erected form be less than 10 $\mathrm{cm}$, penetration might be troublesome, however shorter than $7.5 \mathrm{~cm}$ in stretched form should be candidate to penile lengthening procedures [10].

\section{Conclusion}

Mean flaccid length of Iranian soldiers' penis is $7.87 \mathrm{~cm}$ and flaccid stretched length is $12.22 \mathrm{~cm}$ and mid shaft flaccid circumference is $8.49 \mathrm{~cm}$. Penile parameters have no significant correlation with soldiers' height and age more than $18 \mathrm{y} /$ old. So, these data can be used by both physicians and people to reach a better determination.

\section{Acknowledgments}

The authors gratefully acknowledge the Imam Sajjad Hospital.

\section{Conflict of Interest}

The authors declared no conflict of interest regarding publication of this paper.

\section{References}

1. Habous M, Tealab A, Williamson B, Binsaleh S, El Dawy S, Mahmoud S, et al. Erect penile dimensions in a cohort of 778 Middle Eastern men: establishment of a nomogram. The journal of sexual medicine. 2015;12(6):1402-6. [DOI:10.1111/ jsm.12894] [PMID]

2. Mehraban D, Salehi M, Zayeri F. Penile size and somatometric parameters among Iranian normal adult men. International journal of impotence research. 2007;19(3):303-9. [DOI:10.1038/
[D. sj.ijir.3901532] [PMID]

3. Park S, Chung JM, Kang DI, Ryu DS, Cho WY, Lee SD. The Change of Stretched Penile Length and Anthropometric Data in Korean Children Aged 0-14 Years: Comparative Study of Last 25 Years. Journal of Korean medical science. 2016;31(10):1631-4. [DOI:10.3346/ jkms.2016.31.10.1631] [PMID] [PMCID]

4. Mondaini N, Ponchietti R, Gontero P, Muir G, Natali A, Caldarera E, et al. Penile length is normal in most men seeking penile lengthening procedures. International Journal of Impotence Research. 2002;14(4):283-6. [DOI:10.1038/ sj.ijir.3900887] [PMID]

5. Tiggemann M, Martins Y, Churchett L. Beyond muscles: Unexplored parts of men's body image. Journal of health psychology. 2008;13(8):116372. [DOI:10.1177/1359105308095971] [PMID]

6. Prause N, Park J, Leung S, Miller G. Women's preferences for penis size: a new research method using selection among 3D models. PLoS One. 2015;10(9):e0133079. [DOI:10.1371/journal. pone.0133079] [PMID] [PMCID]

7. Herbenick D, Schick V, Reece M, Sanders SA, Fortenberry JD. The Development and Validation of the Male Genital Self-Image Scale: Results from a Nationally Representative Probability Sample of Men in the U nited S tates. The 
journal of sexual medicine. 2013;10(6):1516-25. [DOI:10.1111/jsm.12124] [PMID]

8. Son H, Lee H, Huh J-S, Kim SW, Paick J-S. Stud ies on s elf-e steem of p enile s ize in young Korean m ilitary m en. Asian J Androl. 2003;5:185-9.

9. Jamison PL, Gebhard PH. Penis size increase between flaccid and erect states: an analysis of the Kinsey data. Journal of sex research. 1988;24(1):177-83. [DOI:10.1080/00224498809551408] [PMID]

10. Wessells H, Lue TF, McAninch JW. Penile length in the flaccid and erect states: guidelines for penile augmentation. The Journal of urology. 1996;156(3):995-7. [DOI:10.1016/S00225347(01)65682-9]

11. Sengezer M, Öztürk S, DevecI M. Accurate method for determining functional penile length in Turkish young men. Annals of plastic surgery. 2002;48(4):381-5. [DOI:10.1097/00000637200204000-00008] [PMID]

12. Son H. Normal penile size and self esteem about penile size of the third decade men in Korea. Korean J Urol. 1999;40(8):1037.

13. Schonfeld WA, Beebe GW. Normal growth and variation in the male genitalia from birth to maturity. The Journal of urology. 1942;48(6):759-77. [DOI:10.1016/S0022-5347(17)70767-7]

14. Promodu K, Shanmughadas K, Bhat S, Nair $\mathrm{K}$. Penile length and circumference: an Indian study. International journal of impotence research. 2007;19(6):558-63. [DOI:10.1038/ sj.ijir.3901569] [PMID]

15. Khan S, Somani B, Lam W, Donat R. Establishing a reference range for penile length in Caucasian British men: a prospective study of 609 men. BJU international. 2012;109(5):740-4. [DOI:10.1111/ j.1464-410X.2011.10338.x] [PMID]

16. Veale D, Miles S, Bramley S, Muir G, Hodsoll J. Am I normal? A systematic review and construction of nomograms for flaccid and erect penis length and circumference in up to 15521 men. BJU international. 2015;115(6):978-86. [DOI:10.1111/bju.13010] [PMID]

17. Li C-Y, Kayes O, Kell PD, Christopher N, Minhas S, Ralph DJ. Penile suspensory ligament division for penile augmentation: indications and results. European urology. 2006;49(4):729-33. [DOI:10.1016/j.eururo.2006.01.020] [PMID]

18. Aaronson IA. Micropenis: medical and surgical implications. The Journal of urology. 1994;152(1):4-14. [DOI:10.1016/S00225347(17)32804-5]

19. Colombo F, Casarico A. Penile enlargement.
Current opinion in urology. 2008;18(6):5838. [DOI:10.1097/MOU.0b013e32830fe427] [PMID]

20. Dillon B, Chama N, Honig S. Penile size and penile enlargement surgery: a review. International journal of impotence research. 2008;20(6):51929. [DOI:10.1038/ijir.2008.14] [PMID] 